\title{
Indeks Massa Ventrikel Kiri dengan Disfungsi Diastole pada Pasien Konsentrik Penyakit Jantung Hipertensi
}

\author{
Chaerul Achmad, ${ }^{1}$ Erwan Martanto, ${ }^{1}$ Toni Mustahsani Aprami, ${ }^{1}$ \\ Augustine Purnomowati, ${ }^{1}$ R. Reni Farenia Soedjana Ningrat, ${ }^{2}$ Mega Febrianora $^{1}$ \\ ${ }^{1}$ Departemen Kardiologi dan Kedokteran Vaskular, RSUP Dr. Hasan Sadikin, Bandung, \\ ${ }^{2}$ Departemen Fisiologi, Fakultas Kedokteran, Universitas Padjadjaran, Bandung, Indonesia
}

\begin{abstract}
Abstrak
Hipertrofi ventrikel kiri ditunjukkan secara objektif dengan peningkatan indeks massa ventrikel kiri (IMVK). Peningkatan massa ventrikel kiri dan dilatasi jantung ruang adalah parameter untuk penyakit jantung hipertensi (PJH). Remodeling jantung ini mengubah fungsi jantung yang mengakibatkan disfungsi diastolik. Penelitian ini bertujuan menemukan korelasi antara IMVK dan disfungsi diastolik pada pasien PJH konsentrik. Terdapat 49 pasien PJH konsentrik. Dari 49 pasien, 43 pasien dilibatkan, 15 laki-laki (35\%) dan 28 perempuan (65\%) memenuhi kriteria inklusi. Penelitian dilakukan di Cardiac Centre RSUP Dr. Hasan Sadikin Bandung periode 1 Oktober 201415 Februari 2015. Pemeriksaan tinggi dan berat badan menggunakan alat SMIC ZT 120. Pemeriksaan ekokardiografi standar dilakukan dan fungsi diastolik dinilai dengan pemeriksaan E/e' menggunakan mesin ekokardiografi Vivid 7. Usia rata-rata subjek adalah 56,56 tahun dan indeks massa tubuh rata-rata adalah $25,96 \mathrm{~kg} / \mathrm{m}^{2}$. Tekanan darah sistole rata-rata 145,51 (SD 21,969) $\mathrm{mmHg}$ dan diastole rata-rata 85,13 (SD 10,227) $\mathrm{mmHg}$. Frekuensi denyut jantung rata-rata 74,07 kali/menit. Fraksi ejeksi rata-rata 73,02. Obat yang secara teratur diminum oleh subjek angiotensin-converting enzyme inhibitor pada 17 orang (40\%), calcium channel blocker 19 orang (44\%), betablocker 15 orang (35\%), angiotensin II reseptor blocker 9 orang (21\%), dan diuretik 4 orang (9\%). Nilai IMVK rata-rata 130,36 (SD 21,077) g/m². Nilai E/e' rata-rata 10,56 (SD 2,761). Hasil penelitian menunjukkan tidak ada hubungan yang signifikan antara IMVK dan derajat disfungsi diastolik $(\mathrm{p}=0,73)$. Data IMVK dan derajat tingkat disfungsi diastolik terdistribusi normal. Simpulan, tidak terdapat hubungan antara IMVK dan disfungsi diastolik pada pasien PJH jenis konsentrik.
\end{abstract}

Kata kunci: Disfungsi diastolik, hipertensi, hipertrofi ventrikel kiri, indeks massa ventrikel kiri, penyakit jantung hipertensi

\section{Left Ventricular Mass Index with Diastolic Dysfunction in Hypertensive Heart Disease Patients}

\begin{abstract}
Left ventricular hypertrophy was shown with increased left ventricular mass index (LVMI). Increased left ventricular mass and cardiac chamber dilatation are parameters for hypertensive heart disease (HHD). This cardiac remodeling causes changes in heart function resulting in diastolic dysfunction. This study aimed to find the correlation between LVMI and diastolic dysfunction in patients with concentric HHD. We enrolled 49 patients with concentric HHD in Cardiac Centre RSUP Dr. Hasan Sadikin Bandung during 1 October 2014 to 15 February 2015, whom 43 met the inclusion criteria, 15 males (35\%) and 28 females (65\%). The subjects of study height and weight measured using SMIC tool ZT 120. The standard echocardiography examination was performed and diastolic function was assessed by examination of the E/e' using echocardiography machine Vivid 7. The average age of the subjects was 56.56 years with body mass index of $25.96 \mathrm{~kg} / \mathrm{m}^{2}$. The average of systolic blood pressure and diastolic blood pressure were 145.51 (SD 21.969) and 85.13 (SD 10.227) mmHg respectivelly. The average frequency of heart beats was 74.07 bpm and average ejection fraction was 73.02. Drugs regularly consumed by subjects according to the percentage were: angiotensin-converting enzyme inhibitor $\{17(40 \%)\}$, calcium channel blocker $\{19(44 \%)\}$, beta-blocker $\{15$ $(35 \%)\}$, angiotensin II receptor blocker $\{9(21 \%)\}$, and diuretics $\{4(9 \%)\}$. The average value of LVMI was 130.36 $(\mathrm{SD} 21.077) \mathrm{g} / \mathrm{m}^{2}$ and the average value of $\mathrm{E} / \mathrm{e}^{\prime}$ was 10.56 (SD 2.761). The result shows that there was no significant correlation between LVMI and the degree of diastolic dysfunction $(\mathrm{p}=0.73)$. The data LVMI and the degree of diastolic dysfunction levels were normally distributed. In conclusion, there is no correlation between LVMI and diastolic dysfunction in patients with HHD concentric type.
\end{abstract}

Key words: Diastolic dysfunction, hypertension, hypertensive heart disease, left ventricular hypertrophy, LV mass index

Korespondensi: Chaerul Achmad. Departemen Kardiologi dan Kedokteran Vaskular, RSUP Dr. Hasan Sadikin. Jalan Pasteur No. 38, Bandung, Indonesia. HP: +6282218071997. E-mail: Chaerula2015@yahoo.com 


\section{Pendahuluan}

Hipertensi merupakan faktor risiko mayor untuk penyakit jantung koroner atau PJK dan strok. ${ }^{1}$ Hipertensi juga merupakan faktor risiko yang paling sering ditemukan pada gagal jantung. Risiko gagal jantung pada pasien hipertensi jika dibanding dengan tanpa hipertensi meningkat sekitar tiga kali lipat. ${ }^{2}$ Menurut data World Health Organization atau WHO tahun 2008, prevalensi penderita hipertensi berusia 25 tahun atau lebih pada pria adalah $40,6 \%$, sedangkan pada wanita $35,8 \%$. Penderita hipertensi bervariasi berdasar atas letak geografis, di Asia Tenggara prevalensi hipertensi pada pria $37,3 \%$ dan wanita $34,9 \% .^{3}$ Menurut data Riset Kesehatan Dasar (Riskesdas) tahun 2013 prevalensi hipertensi di Indonesia adalah $25,8 \%{ }^{4}$

Hipertensi yang kronik dapat mengakibatkan komplikasi untuk jangka panjang yang sifatnya fatal. Salah satu organ utama yang berkaitan dengan proses kompensasi itu adalah jantung. Data dari American Heart Association pada tahun 2013 menyatakan bahwa pasien dengan tekanan darah $>140 / 90 \mathrm{mmHg}$ yang mengalami serangan jantung sebesar $69 \%$, strok $77 \%$, gagal jantung kongestif $74 \%$, dan menjadi penyebab utama kematian pada 61.762 kematian terjadi di Amerika pada tahun 2009. ${ }^{5}$ Perubahan yang terjadi pada jantung akibat hipertensi kronik meliputi perubahan struktur berupa hipertrofi dan dilatasi, serta perubahan fungsi diakibatkan proses inflamasi dan fibrosis sebagai respons dari perubahan hemodinamik yang terjadi, terutama pada bilik ventrikel kiri. Hipertrofi ventrikel kiri ditunjukkan secara objektif dengan peningkatan indeks massa ventrikel kiri (IMVK) yang lebih besar dibanding dengan angka normal sesuai jenis kelamin melalui pemeriksaan ekokardiografi, dan menjadi karakteristik yang mendasari penegakan diagnosis penyakit jantung hipertensi. ${ }^{6,7}$

Massa ventrikel kiri yang meningkat dan juga dilatasi ruang jantung bersifat progresif. Kedua parameter ini menjadi dasar untuk membedakan pola hipertrofi, yaitu konsentrik dan eksentrik. Kedua pola hipertrofi ini akan memberikan efek buruk jangka panjang bagi penderita penyakit jantung hipertensi. Laporan The Framingham Heart Study dinyatakan bahwa massa ventrikel kiri berhubungan erat dengan morbiditas serta mortalitas kardiovaskular. ${ }^{8}$ Hipertrofi konsentrik sangat berhubungan dengan beban hemodinamik dan abnormalitas struktural yang lebih berat. ${ }^{6}$
Sebuah artikel yang ditulis oleh Muiesan dkk.7 menyatakan bahwa hipertrofi konsentrik adalah pola adaptasi yang paling sering didapatkan dan paling berbahaya pada hipertensi sebelum didapatkan kejadian kardiovaskular. Studi yang dilakukan oleh de Simon dkk., ${ }^{6,9}$ Verdechia dkk., ${ }^{10}$ dan Muiesan dkk. ${ }^{7}$ menunjukkan bahwa hipertrofi konsentrik berhubungan dengan peningkatan risiko kejadian kardiovaskular yang lebih tinggi dibanding dengan hipertrofi eksentrik, termasuk kematian.

Remodeling jantung juga dapat menyebabkan perubahan fungsi jantung sehingga dapat terjadi disfungsi diastole. Standar baku untuk penilaian disfungsi diastole adalah dengan pemeriksaan invasif, namun pemeriksaan ini sudah digantikan dengan pemeriksaan yang bersifat noninvasif. Cara pemeriksaan noninvasif yang paling banyak digunakan adalah pemeriksaan ekokardiografi. ${ }^{11}$ Penilaian fungsi diastole dan derajat disfungsi berdasarkan atas ekokardiografi dapat dilakukan dengan beberapa metode, yaitu mitral inflow, dengan manuver valsava, pulmonary venous flow, color m-mode flow propagation velocities, dan tissue doppler annular early and late diastolic velocities. ${ }^{12}$ Metode untuk pemeriksaan disfungsi diastole yang direkomendasikan oleh European Society of Cardiology (ESC) adalah pemeriksaan rasio antara transmitral inflow doppler dan tissue doppler imaging (TDI) early diastolic velocity (E/e'). Rasio $\mathrm{E} / \mathrm{e}^{\prime} \geq 13$ berhubungan dengan peningkatan terjadi risiko kardiovaskular dan juga independen terhadap massa ventrikel kiri serta ketebalan dinding relatif pada pasien hipertensi. ${ }^{12,13}$ Karena indeks massa ventrikel kiri adalah salah satu indikator hipertropi ventrikel kiri yang dapat menyebabkan disfungsi diastole maka penelitian ini mempunyai tujuan menemukan hubungan antara IMVK dan disfungsi diastole.

\section{Metode}

Subjek adalah pasien hipertensi dengan ventrikel hipertrofi ventrikel kiri tipe konsentrik yang datang berobat ke Cardiac Center RSUP Dr. Hasan Sadikin Bandung mulai dari 1 Oktober 2014 sampai 15 Februari 2015 yang telah setuju untuk mengikuti penelitian ini dan menandatangani persetujuan ikut dalam penelitian atau informed consent. Penelitian ini mempergunakan desain cross-sectional dengan analisis korelasi.

Kriteria inklusi pada penelitian ini adalah 
pasien hipertensi dengan hipertrofi ventrikel kiri tipe konsentrik berdasar atas temuan pada pemeriksaan ekokardiografi. Kriteria eksklusinya mencakup pasien dengan atrial fibrilasi, stenosis aorta, penyakit arteri koroner, kardiomiopati hipertrofik, penyakit jantung katup, diabetes melitus, gagal ginjal kronik, keganasan, trimester ketiga kehamilan, dan atlet.

Ukuran sampel (n) dalam penelitian analisis korelasi ini ditentukan mempergunakan program perhitungan sampel dan power, yaitu Power Application \& Sample Size (PASS) 11 dengan perhitungan menurut test for one correlation. Taraf kemaknaan atau nilai alfa penelitian ini ditentukan sebesar $5 \%(0,05)$ dan nilai power penelitian 95\% dengan perbedaan korelasi o,6 $\left(\alpha=0,05 ; \quad p=95 ; R_{0}=0 ;\right.$ dan $\left.R_{1}=0,6\right)$. Jumlah sampel minimal yang harus diperoleh berdasar atas cara perhitungan program software tersebut adalah 30 sampel. Pengambilan sampel dilakukan secara consecutive sampling terhadap populasi penderita hipertensi dengan hipertrofi ventrikel kiri tipe konsentrik berdasar atas temuan dari ekokardiografi pada 1 Oktober 2014 sampai 15 Februari 2015.

Pada subjek penelitian dilakukan pemeriksaan tinggi badan $(\mathrm{cm})$ dan berat badan $(\mathrm{kg})$ dengan menggunakan alat SMIC ZT fungsi 120. Fungsi diastole tersebut dinilai dengan pemeriksaan E/e' mempergunakan mesin ekokardiografi Vivid 7. Pemeriksaan dilaksanakan oleh ahli jantung konsultan ekokardiografi.

Anamnesis dilaksanakan untuk memperoleh data dasar dari subjek penelitian, di antaranya untuk memastikan subjek penelitian memenuhi kriteria inklusi dan tidak termasuk dalam kriteria eksklusi, lama menderita hipertensi, serta terapi yang telah diberikan. Pemeriksaan fisis meliputi perhitungan denyutjantung, pengukuran tekanan darah mempergunakan alat sphygmomanometer air raksa Riester, pengukuran lingkar pinggang, pengukuran tinggi badan, dan pengukuran berat badan menggunakan alat SMIC ZT 120 dilakukan pada seluruh subjek penelitian.

Analisis statistik dilaksanakan sesuai dengan tujuan penelitian, diawalidengan uraian deskriptif dan uji normalitas menggunakan Uji SaphiroWilks bila jumlah sampel $\leq 50$ atau Kolmogorov Smirnov apabila jumlah sampel $>50$, dilanjutkan dengan analisis uji korelasi antara IMVK dan derajat disfungsi diastole menggunakan analisis korelasi Pearson product moment bila data terdistribusi normal atau dengan Rank Spearman bila data tidak terdistribusi normal.

\section{Hasil}

Terdapat empat puluh sembilan pasien hipertensi memenuhikriteriainklusi.Satupasien didiagnosis diabetes melitus dan penyakit jantung koroner, 4 (empat) pasien didiagnosis diabetes melitus, dan satu pasien didiagnosis gagal ginjal kronik sehingga didapatkan 43 pasien yang memenuhi kriteria inklusi dan tidak termasuk eksklusi yang menjadi subjek dalam penelitian ini. Data usia, jenis kelamin, berat badan, tinggi badan, tekanan darah sistole dan tekanan darah diastole, BMI, indeks massa ventrikel kiri, ketebalan dinding

Tabel 1 Karakteristik Subjek Penelitian

\begin{tabular}{lcc}
\hline \multicolumn{1}{c}{ Variabel } & Rata-rata (SD) & n (\%) \\
\hline Usia (tahun) & $56,56(11,044)$ & \\
Jenis kelamin: & & \\
$\quad$ - laki-laki (\%); & & $15(35 \%)$ \\
$\quad$ - perempuan (\%). & $28(65 \%)$ \\
Tekanan darah sistole (mmHg) & \\
Tekanan darah diastole (mmHg) & $145,51(21,969)$ & \\
Denyut jantung (bpm) & $85,13(10,227)$ & \\
Indeks massa tubuh (kg/m $\left.{ }^{2}\right)$ & $74,07(10,329)$ & \\
Fraksi ejeksi (\%) & $25,96(4,97)$ & \\
Riwayat obat antihipertensi: & $73,02(8,584)$ & \\
$\quad$ angiotensin converting enzyme inhibitor; & & \\
$\quad$ angiotensin II receptor blocker; & & $17(40 \%)$ \\
beta-blocker; & & $9(21 \%)$ \\
$\quad$ calcium channel blockers; & & $15(35 \%)$ \\
diuretik. & & $19(44 \%)$ \\
& & $4(9 \%)$ \\
\hline
\end{tabular}


Tabel 2 Nilai LVMI dan Derajat Disfungsi Diastole (E/e')

\begin{tabular}{lc}
\hline \multicolumn{1}{c}{ Variabel } & Rata-rata (SD) \\
\hline LVMI (ASE) $(\mathrm{g} / \mathrm{m} 2)$ & $130,36(21,077)$ \\
E/e' & $10,56(2,761)$ \\
\hline
\end{tabular}

relatif, dan riwayat obat antihipertensi disajikan pada Tabel 1.

Tabel 1 memperlihatkan uji normalitas pada data numerik mempergunakan Uji Shapiro Wilk untuk $\mathrm{n} \leq 50$. Hasil uji normalitas menunjukkan bahwa usia, denyut jantung, indeks massa tubuh, dan fraksi ejeksi terdistribusi normal, sedangkan data pada variabel lain juga terdistribusi secara normal.

Pada penelitian ini, subjek laki-laki sebanyak 15 orang (35\%) dan perempuan 28 orang (65\%), usia rata-rata subjek $56,56 \pm 11,044$ tahun dan indeks massa tubuh rata-rata $25,96 \pm 4,97 \mathrm{~kg} / \mathrm{m}^{2}$. Tekanan darah sistole rata-rata $145,51 \pm 21,969$ $\mathrm{mmHg}$ dan juga tekanan darah diastole rata-rata $85,13 \pm 10,227 \mathrm{mmHg}$. Frekuensi denyut jantung rata-rata pada subjek $74,07 \pm 10,329 \mathrm{bpm}$. Fraksi ejeksi rata-rata adalah $73,02 \pm 8,584 \%$. Riwayat pengobatan memakai angiotensin converting enzyme (ACE) inhibitor terdapat pada 17 pasien (40\%), angiotensin II receptor blocker (ARB) sebanyak 9 pasien (21\%), beta-blocker sebanyak 15 pasien (35\%), calcium channel blockers (CCB) sebanyak 19 pasien (44\%), dan diuretik sebanyak 4 pasien (9\%).

Pengukuran IMVK dilakukan dengan metode 2D, metode $\mathrm{M}$-mode, dan pengukuran tingkat disfungsi diastole dicatat dalam Tabel 2. IMVK rata-rata penelitian ini $130,36 \pm 21,077$, sedangkan derajat disfungsi diastole rata-rata $10,56 \pm 2,761$ (Uji Korelasi Pearson).

Berdasarkan Tabel 2 di atas, analisis untuk menentukan hubungan antara IMVK dan derajat disfungsi diastole dilakukan menggunakan Uji Korelasi Pearson karena data IMVK dan derajat disfungsi diastole terdistribusi secara normal. Hasil yang diperoleh seperti yang ditunjukkan pada Tabel 3.

\section{Tabel 3 Hubungan IMVK dengan Derajat Disfungsi Diastole}

\begin{tabular}{lcc}
\hline Parameter & $\begin{array}{c}\text { Koefisien } \\
\text { Korelasi (r) }\end{array}$ & Nilai p \\
\hline LMVI - E/e' & 0,057 & 0,73 \\
\hline
\end{tabular}

\section{Pembahasan}

Subjek perempuan berjumlah $65 \%$, sedangkan laki-laki 35\%. Hal ini sesuai dengan prevalensi kasus hipertensi di Indonesia berdasar atas data Riskesdas 2013. ${ }^{4}$ Usia subjek penelitian ratarata adalah 56,56 $\pm 11,044$ tahun, serupa dengan studi-studi yang juga menilai IMVK, di antaranya penelitian oleh Baloch dkk. ${ }^{14}$ dan Almuntaser dkk. ${ }^{15}$ Subjek penelitian ini memiliki nilai IMVK bervariasi, mulai dari normal sampai memenuhi kriteria untuk konsentrik hipertrofi. Penelitian ini menunjukkan nilai IMVK bervariasi mulai dari normal hingga tinggi (hipertrofi). IMVK rata-rata pada penelitian ini adalah $130,36 \pm 21,077 \mathrm{~g} / \mathrm{m}^{2}$, hasil ini lebih kecil dibanding dengan penelitian serupa yang dilakukan oleh Baloch dkk. ${ }^{14}$ dengan nilai $158,03 \pm 35,87 \mathrm{~g} / \mathrm{m}^{2}$ dan lebih kecil daripada studi oleh Masugata dkk. ${ }^{16}$ sebesar $143 \pm 27 \mathrm{~g} / \mathrm{m}^{2}$. E/e' rata-rata penelitian ini adalah $10,56 \pm 2,761$. Hasil ini lebih kecil daripada studi oleh Masugata dkk. ${ }^{16}$ sebesar $13,4 \pm 5,4$.

Penelitian pada hipertrofi ventrikel kiri dan disfungsi diastole pada anak dan remaja dengan hipertensi esensial oleh Lee dkk. ${ }^{17}$ menyimpulkan bahwa tidak ada hubungan yang signifikan antara IMVK dan disfungsi diastole. Disfungsi diastole adalah well-described type of cardiovascular organ damage pada pasien hipertensi. Disfungsi diastole terjadi bersamaan dengan fibrosis dan iskemia miokardium pada hipertensi sistemik kronik sehingga disfungsi diastole ventrikel kiri dengan restriksi pengisian ventrikel kiri dianggap sebagai tanda hypertensive heart disease. ${ }^{18}$

Penilaian hipertrofi ventrikel kiri dilakukan dengan mengukur ketebalan dinding merupakan faktor sangat penting dalam menilai keparahan disfungsi ventrikel kiri. ${ }^{16}$ Indeks massa ventrikel kiri mencerminkan beratnya hipertrofi ventrikel kiri sehingga secara teoritis IMVK mencerminkan tingkat disfungsi diastole. Salah satu faktor yang dapat mengganggu pemahaman ini adalah obatobatan antihipertensi. Pada penelitian ini subjek secara teratur mengonsumsi obat antihipertensi. Ada lima obat antihipertensi yang diminum oleh subjek penelitian ini: ACE inhibitor, ARB, betablocker, calcium channel blocker, dan diuretik. Sebagian dari subjek mengonsumsi obat antihipertensi tunggal, sisanya mengonsumsi dua atau tiga kombinasi obat antihipertensi.

Beberapa penelitian memperlihatkan bahwa obat antihipertensi akan meningkatkan disfungsi diastole. Meta-analisis melaporkan bahwa betablocker menunjukkan perbaikan terhadap massa 
ventrikel kiri. Studi tersebut juga menyimpulkan bahwa ACE inhibitor lebih efektif daripada terapi lini pertama lain seperti diuretik, beta-blocker, serta calcium channel blockers. ACE inhibitor mengurangi massa ventrikel kiri lebih besar bila dibandingkan dengan beta-blocker dan diuretik, sedangkan kemampuan calcium channel blocker berada di antara ACE inhibitor, beta-blocker, dan diuretik. Massa ventrikel kiri menurun sebesar $13 \%$ dengan angiotensin II receptor blocker, $11 \%$ dengan pemberian calcium channel blocker, $10 \%$ dengan ACE inhibitor, 8\% dengan diuretik, dan $6 \%$ dengan beta-blocker. ${ }^{19}$

Gaudio dkk. ${ }^{20}$ melaporkan bahwa irbesartan menurunkan IMVK sebesar 23,2\% dan amlodipin menurunkan IMVK sebesar $11,4 \%$. Studi oleh Beltman dkk. ${ }^{21}$ dan Terpstra dkk. ${ }^{22}$ menunjukkan bahwa amlodipin menurunkan tekanan darah diastole lebih baik daripada lisinopril. Amlodipin dan lisinopril juga menurunkan IMVK. Bruder dkk. ${ }^{23}$ melaporkan bahwa losartan mengurangi hipertrofi pada ventrikel kiri lebih baik daripada obat atenolol. Pengurangan massa ventrikel kiri dengan pemberian obat losartan juga berkorelasi signifikan dengan penurunan mortalitas serta morbiditas kardiovaskular. ${ }^{24}$ Sebuah studi yang dilakukan Teniente-Valente dkk. ${ }^{25}$ menemukan bahwa captopril mengurangi tekanan sistole dan diastole serta menurunkan IMVK dari 155,4 $\pm 32,9$ ke 121,7 $\pm 29,14 \mathrm{mmHg}$. Hasil ini secara signifikan memperbaiki fungsi diastolik. Studi percobaan ELVERA menemukan ACE inhibitor dan calcium channel blocker adalah obat yang paling ampuh mengurangi massa ventrikel kiri. Pemberian betablocker dan diuretik kurang efektif. ${ }^{22}$ Pencapaian tekanan darah terkontrol dapat memperbaiki fungsi sistolik dan diastolik pada pasien penyakit jantung hipertensi. ${ }^{15}$ Beltman dkk. ${ }^{21}$ melakukan studi yang menunjukkan amlodipin dan lisinopril menurunkan IMVK sebesar 11,0 g/ $\mathrm{m}^{2}$ dan 12,6 $\mathrm{g} / \mathrm{m}^{2}$ secara signifikan setelah setahun terapi. Penelitian Malmqvist dkk. ${ }^{26}$ menemukan bahwa IMVK berkurang $115 \pm 21 \mathrm{~g} / \mathrm{m}^{2}$ dengan captopril pada bulan ke-12 terapi.

Bruder dkk. ${ }^{23}$ melaporkan bahwa amlodipin pada dosis $5^{-10} \mathrm{mg}$ menurunkan IMVK secara signifikan dari $160 \pm 30$ menjadi $137 \pm 26 \mathrm{~g} / \mathrm{m}^{2}$ setelah 3 (tiga) bulan dan tetap stabil pada bulan keenam. Temuan ini sesuai dengan studi oleh Fak dkk. ${ }^{27}$ yang menunjukkan amlodipin efektif dalam mengurangi hipertrofi ventrikel kiri pada pasien dengan hipertensi yang ringan sampai hipertensi sedang setelah 6 (enam) bulan terapi. Studi yang dilakukan oleh Prasquier dkk. ${ }^{28}$ memperlihatkan bahwa captopril menurunkan ketebalan dinding posterior dari 14,8 $\mathrm{mm}$ menjadi 13,8 $\mathrm{mm}$ setelah enam bulan terapi. Sementara ketebalan septum menurun dari 17,2 mm menjadi 15,7 mm dengan captopril. Massa ventrikel kiri dan juga IMVK masing-masing menurun dari $456 \mathrm{~g} / \mathrm{m}^{2}$ dan 232 $\mathrm{g} / \mathrm{m}^{2}$ menjadi $372 \mathrm{~g} / \mathrm{m}^{2}$ dan $190 \mathrm{~g} / \mathrm{m}^{2} .{ }^{28}$ Subjek penelitian ini memakai obat antihipertensi secara teratur selama lebih dari satu tahun. Kondisi ini dapat mengganggu hasil studi karena perbaikan IMVK dan fungsi diastolik.

Kegemukan dan obesitas adalah gangguan gizi yang paling umum dan telah menjadi fokus utama terkait hubungan antara obesitas dan morbiditas kardiovaskular. Kegemukan merupakan faktor risiko independen pada penyakit kardiovaskular. Kegemukan mampu mengakibatkan perubahan kardiovaskular atau kemudian menjadi masalah kardiovaskular. ${ }^{29}$ Sebuah penelitian oleh Chadha dkk..$^{30}$ memperlihatkan bahwa IMT berhubungan secara signifikan dengan fungsi sistole dan fungsi diastole ventrikel kiri. Perubahan pada fungsi diastolik ventrikel kiri sering meningkat pada pasien dengan obesitas. Kossaify dan Nicolas ${ }^{31}$ juga menemukan bahwa kelebihan berat badan dan obesitas merupakan dampak negatif yang independen terhadap fungsi diastolik. Fenk dkk. ${ }^{32}$ melakukan yang sebaliknya, mereka menemukan bahwa penurunan berat badan dalam jangka panjang pada pasien obesitas berkaitan dengan peningkatan fungsi ventrikel kiri dan kapasitas ventrikel kiri. Pada penelitian ini, IMT subjek penelitian bervariasi dari subjek dengan berat badan kurang sampai obesitas. Subjek penelitian yang obesitas dapat mengganggu hasil penelitian ini karena penelitian sebelumnya menunjukkan obesitas berhubungan dengan fungsi diastolik.

Keterbatasan penelitian ini disebabkan oleh banyak kriteria eksklusi sehingga hanya sedikit sampel yang dapat diperoleh. Penelitian lebih lanjut disarankan untuk menggunakan data yang lebih besar jumlahnya. Selain itu, obesitas juga sebaiknya dimasukkan ke dalam kriteria eksklusi dan riwayat pengobatan yang kurang dari enam bulan dapat dimasukkan sebagai kriteria inklusi.

Penelitian ini menimbulkan dampak etika yang mengganggu kenyamanan pasien karena membutuhkan waktu yang cukup lama pada saat pemeriksaan ekokardiografi, wawancara untuk mendapatkan persetujuan mengikuti penelitian, pengukuran tinggi badan, berat badan, dan juga tekanan darah. 


\section{Simpulan}

Tidak terdapat hubungan antara indeks massa ventrikel kiri dan disfungsi diastole pada pasien jantung hipertensi tipe konsentrik.

\section{Daftar Pustaka}

1. Chobanian AV, Bakris GL, Black HR, Cushman WC, Green LA, Izzo JL, dkk.; the National High Blood Pressure Education Program Coordinating Committee. Seventh report of the joint national committee on prevention, detection, evaluation, and treatment of high blood pressure. Hypertension. 2003;42(6):1206-52.

2. Levy D, Larson MG, Vasan RS, Kannel WB, Ho KKL. The progression from hypertension to congestive heart failure. JAMA. 1996;275(20):1557-62.

3. World Health Organization. Global status report on noncommunicable diseases 2010. Geneva, Switzerland: WHO Press; 2011.

4. Badan Penelitian dan Pengembangan Kesehatan, Kemenkes RI. Riset kesehatan dasar (Riskesdas) 2013. Jakarta: Kemenkes RI; 2013.

5. Roger VL, Go AS, Lloyd-Jones DM, Benjamin EJ, Berry JD, Borden WB, dkk.; American Heart Association Statistics Committee and Stroke Statistics Subcommittee. Heart disease and stroke statistics--2012 update: a report from the American Heart Association. Circulation. 2012;125(1):e2-220.

6. de Simone G, Verdecchia P, Pede S, Gorini M, Maggioni AP. Prognosis of inappropriate left ventricular mass in hypertension: the MAVI Study. Hypertension. 2002;40(4):470-6.

7. Muiesan ML, Salvetti M, Monteduro C, Bonzi B, Paini A, Viola S, dkk. Left ventricular concentric geometry during treatment adversely affects cardiovascular prognosis in hypertensive patients. Hypertension. 2004;43(4):731-8.

8. Stevens SM, Reinier K, Chugh SS. Increased left ventricular mass as a predictor of sudden cardiac death: is it time to put it to the test? Circ Arrhythm Electrophysiol. 2013;6(1):212-7.

9. de Simone G, Kitzman DW, Chinali M, Oberman A, Hopkins PN, Rao DC, dkk. Left ventricular concentric geometry is associated with impaired relaxation in hypertension: the HyperGEN study. Eur Heart J. 2005;26(10):1039-45.

10. Verdecchia P, Schillaci G, Borgioni C, Ciucci A, Battistelli M, Bartoccini C, dkk. Adverse prognostic significance of concentric remodeling of theleft ventriclein hypertensive patients with normal left ventricular mass. J Am Coll Cardiol. 1995;25(4):871-8.

11. Mottram PM, Marwick TH. Assessment of diastolic function: what the general cardiologist needs to know. Heart. 2005;91(5):681-91.

12. Nagueh SF, Appleton CP, Gillebert TC, Marino PN, Oh JK, Smiseth OA, dkk. Recommendations for the evaluation of left ventricular diastolic function by echocardiography. Eur $J$ Echocardiogr. 2009;10(2):165-93.

13. Mancia G, Fagard R, Narkiewicz K, Redon J, Zanchetti A, Bohm M, dkk. 2013 ESH/ ESC Guidelines for the management of arterial hypertension: the Task Force for the Management of Arterial Hypertension of the European Society of Hypertension (ESH) and of the European Society of Cardiology (ESC). Eur Heart J. 2013;34(28):2159-219.

14. Baloch DM, Rasheed SZ, Rajput IA, Samad A. Prevalence of left ventricular diastolic dysfunction in patients with left ventricular hypertrophy. Pak Heart J. 2010;43(1-2):206.

15. Almuntaser I, Mahmud A, Brown A, Murphy R, King G, Crean P, dkk. Blood pressure control determines improvement in diastolic dysfunction in early hypertension. Am J Hypertens. 2009;22(11):1227-31.

16. Masugata $H$, Senda S, Inukai M, Murao K, Hosomi N, Iwado Y, dkk. Differences in left ventricular diastolic dysfunction between eccentric and concentric left ventricular hypertrophy in hypertensive patients with preserved systolic function. J Int Med Res. 2011;39(3):772-9.

17. Lee H, Kong YH, Kim KH, Huh J, Kang IS, Song J. Left ventricular hypertrophy and diastolic function in children and adolescents with essential hypertension. Clin Hypertens. 2015;21:21.

18. Agu NC, McNiece Redwine K, Bell C, Garcia KM, Martin DS, Poffenbarger TS, dkk. Detection of early diastolic alterations by tissue doppler imaging in untreated childhood-onset essential hypertension. J 
Am Soc Hypertens. 2014;8(5):303-11.

19. Fagard RH, Celis H, Thijs L, Wouters S. Regression of left ventricular mass by antihypertensive treatment. Hypertension. 2009;54(5):1084-91.

20. Gaudio C, Ferri FM, Giovannini M, Pannarale G, Puddu PE, Vittore A, dkk. Comparative effects of irbesartan versus amlodipine on left ventricular mass index in hypertensive patients with left ventricular hypertrophy. $\mathrm{J}$ Cardiovasc Pharmacol. 2003;42(5):622-8.

21. Beltman FW, Heesen WF, Smit AJ, May JF, de Graeff PA, Havinga TK, dkk. Effects of amlodipine and lisinopril on left ventricular mass and diastolic function in previously untreated patients with mild to moderate diastolic hypertension. Blood Press. 1998;7(2):109-17.

22. Terpstra WF, May JF, Smit AJ, de Graeff PA, Havinga TK, van den Veur E, dkk. Longterm effects of amlodipine and lisinopril on left ventricular mass and diastolic function in elderly, previously untreated hypertensive patients: the ELVERA trial. J Hypertens. 2001;19(2):303-9.

23. Bruder O, Christoph JJ, Bell M, Rummel R, Boehm G, Klebs S, dkk. Effects of the combinations of amlodipine/ valsartan versus losartan/hydrochlorothiazide on left ventricular hypertrophy as determined with magnetic resonance imaging in patients with hypertension. J Drug Assess. 2012;1(1):1-10.

24. Okin PM, Devereux RB, Jern S, Kjeldsen SE, Julius S, Nieminen MS, dkk. Regression of electrocardiographic left ventricular hypertrophy during antihypertensive treatment and the prediction of major cardiovascular events. JAMA. 2004;292(19): 2343-9.

25. Teniente-Valente R, Solorio S, Vargas-Salado
E, Aguirre-Vázquez C, Hernández-González MA, Olvera-Lopez JA, dkk. Improvement of diastolic function after regression of left ventricular hypertrophy. Arch Cardiol Mex. 2008;78(4):392-9.

26. Malmqvist K, Kahan T, Isaksson H, Ostergren $\mathrm{J}$. Regression of left ventricular mass with captopril and metoprolol, and the effects on glucose and lipid metabolism. Blood Press. 2001;10(2):101-10.

27. Fak AS, Okucu M, Tezcan H, Bodur G, Kotay A. Effects of antihypertensive therapy with amlodipine on left ventricular mass and diastolic function. Arch Turk Soc Cardiol. 1995;23(5):336-42.

28. Prasquier R, Dufloux MA, Chatellier G, Plouin $\mathrm{PF}$, Ménard D, Corvol P, dkk. Comparison of the effect of captopril and minoxidil on left ventricular mass. Results of a 6-month comparative double-blind test. Arch $\mathrm{Mal}$ Coeur Vaiss. 1987;80(6):911-8.

29. Egan B, FitzpatrickA, Juni J, Buda AJ,Zweifler A. Importance of overweight in studies of left ventricular hypertrophy and diastolic function in mild systemic hypertension. Am J Cardiol. 1989;64(12):752-5.

30. Chadha DS, Swamy A, Malani SK, Ganjoo RK, Mathew OP. Impact of body mass index on left ventricular function. Med J Armed Forces India. 2009;65(3):203-7.

31. Kossaify S, Nicolas N. Impact of overweight and obesity on left ventricular diastolic function and value of tissue doppler echocardiography. Clin Med Insights Cardiol. 2013;7:43-50.

32. Fenk S, Fischer M, Strack C, Schmitz G, Loew T, Lahmann C, dkk. Successful weight reduction improves left ventricular diastolic function and physical performance in severe obesity. Int Heart J. 2015;56(2):196-202. 